\title{
Modeling Students' Perceived Self-efficacy and Importance toward Core Ideas and Work and Life Skills in Science Education
}

\author{
Helen Semilarski ${ }^{*}$, Regina Soobard, Miia Rannikmäe \\ Centre for Science Education, Faculty of Science and Technology, University of Tartu, Estonia \\ *Corresponding Author: helen.semilarski@ut.ee
}

\section{ABSTRACT}

Developing student self-efficacy and conceptualizing the importance of core ideas are seen as important learning areas in science education. Such core ideas can be elucidated with respect to the science discipline as well as interdisciplinary learning. Schools can be expected to promote high levels of students' self-efficacy in acquiring major disciplinary ideas and guiding students toward recognizing the importance of gaining work and life skills. This research sought to develop models describing students' gains in perceived self-efficacy and importance of work and life skills as well as indicating the relationship with both disciplinary and interdisciplinary core ideas in science education. Using a validated instrument, data were collected from Grade $8(n=218)(14-15$ years old) and Grade $11(n=95)$ (17-18 years old) students. Models were created based on confirmatory factor analysis and parallel analysis. This research shows that there is need to make changes in secondary school studies so as to more clearly recognize a framework for both disciplinary and interdisciplinary core ideas, shown to be important for enabling students to prepare for their future life and careers.

KEY WORDS: disciplinary core ideas; interdisciplinary core ideas; modeling; perceived importance; perceived self-efficacy; work and life skills

\section{INTRODUCTION}

T n today's world, science and technology play an increasing role in both everyday life and in many careers (OECD, 2016). It becomes important both in middle and secondary school science studies and science careers that students develop conceptualization of the learning (core ideas), associated interdisciplinary skills, and be competent to prepare for their future life and possible careers. Unfortunately, science subjects and science careers are not seen as attractive for students (OECD, 2016; Bybee \& McCrae, 2011; Osborne et al., 2003) and it is not surprising, a major aim within science education is to raise the student's motivation for science studies and careers. One suggested approach is by integrating the science to be acquired with a real-life context (Hildebrand, 2018; Teppo et al., 2017). In this way, learning experiences can be linked with personal aspirations, interests, or cultural/personal experiences of students (Holbrook \& Rannikmäe, 2009; Van Aalsvoort, 2004). Going further, relevance can be promoted further by linking science to potential future careers as shown through a European Union (EU) project "Promoting Youth Scientific Career Awareness and Its Attractiveness through Multi-Stakeholder Co-operation."

One of the prevalent concerns within science education is that it is presented through conceptual science topics, promoting the gaining of fragmented or isolated knowledge and thus leading to students lacking a clear picture about the relevance of acquired topics and how they are interrelated (Harlen et al., 2010, 2015). To counteract this, it is suggested that major conceptual topics can be considered as core ideas (Krajcik \& Delen, 2017) and that, through conceptualization, the core ideas can promote relevance (Holbrook \& Rannikmäe, 2010). Where the conceptualization is interrelated with skills associated with life and the world of work, it is further suggested that it can promote student motivation in learning the science.

It is not surprising, therefore, that Harlen et al. (2015) suggested it is important for students to create links between topics (seen as core ideas) and the incorporation of learning attributes that have a direct relationship with the world of work and hence related careers.

It is possible for core ideas to be divided into two areas:

- Disciplinary core ideas - which are linked with specific subject topics or sub-topics (e.g. from biology, genetic variety, or from geography, weather, and climate). These disciplinary core ideas are subject concepts;

- Interdisciplinary core ideas, which are central to learning but transferrable across different subjects. These interdisciplinary core ideas are models and systems.

Devising models and creating systems can be used as examples to illustrate interdisciplinary core ideas. These core ideas are transferrable across different disciplines. For example, creating 
models which are used in mathematics and history (creating model of pyramids) are also used in other disciplines, for example, in biology (creating a model of DNA) or chemistry (creating a model of atom). These interdisciplinary core ideas can be seen as a context for learning and can help students gain a clearer overview by core ideas (Krajcik \& Delen, 2017; Harlen et al., 2010, 2015). The learning that students receive from acquiring disciplinary and interdisciplinary core ideas can facilitate motivation toward science-related careers.

Different research studies on Estonia secondary school students showed that while students' perceived self-efficacy toward science learning was high, this was noticeably lower in learning work and life skills (Soobard \& Rannikmäe, 2015). Furthermore, the research undertaken by Soobard et al. (2018) indicated that Grade 12 students perceived self-efficacy utilizing work and life skills was much lower in some areas (e.g., problem-solving skills), compared with others, such as creativity and imagination. Based on their outcomes, they suggested that it was important to rethink the manner in which science content was presented to students and to consider presenting science content in a way to support students' perceived self-efficacy.

The focus of this study was to develop models about students' perceived self-efficacy and its importance toward work and life skills and core ideas among Grades 8 and 11 students. The following research questions were put forward:

- RQ1: What are the students' perceived self-efficacy and importance of disciplinary and interdisciplinary core ideas among Grades 8 and 11 students and how these are modeled?

- RQ2: What are the students' perceived self-efficacy and importance of work and life skills among Grades 8 and 11 students and how these are modeled?

\section{Theoretical Background}

\section{Core ideas in science education}

Researchers have suggested there is a need to emphasize and use core ideas in science and science education (Krajcik \& Delen, 2017; Stevens et al., 2009). Such core ideas are especially meaningful when interrelating topics and help to make sense of connections (Clark, 1997; Harlen et al., 2015). In fact, core ideas can be defined as those ideas which by conceptualization can aid students learning about themselves (Harlen et al., 2010, 2015).

Conceptualization of core ideas supports students' deeper learning, and based on that, allows students to apply what they have learned (Krajcik \& Delen, 2017). Nevertheless, there are different core ideas:

- Disciplinary core ideas - which are linked with specific subject topics or sub-topics (e.g., from biology, genetic variety, or from geography, weather, and climate). These disciplinary core ideas are subject concepts;

- Interdisciplinary core ideas, which are central to learning but transferrable across different subjects. These interdisciplinary core ideas are, for example, models and systems.
To use core ideas meaningfully in a science lesson, the interconnection of core ideas is needed, as well as the interrelationships within different disciplines (Greeno \& Engeström, 2014; NRC, 2007). By applying core ideas in different science subjects, connections between different disciplines can be recognized by teachers and students. Ideas that are taken to be core are invaluable in that they can form thinking tools that can be indispensable in explaining and predicting a host of phenomena (Krajcik \& Delen, 2017). These thinking tools can help to develop well-structured learning across school years through the different levels of education (from primary school level to secondary school level) (NRC, 2013). Thinking tools are also important because they can interrelate with the promotion of interdisciplinary capability - core ideas require both thinking and doing.

Determining core ideas is not straightforward - although topics can be taken as core ideas, in many cases, these are too board and encompass a range of core ideas. This is the reason why, in this study, core ideas are also seen as building a framework. It is also really important to emphasize both disciplinary and interdisciplinary core ideas and their value in science education.

The importance of referring to disciplinary and interdisciplinary core ideas as a study frame is seen as meaningful (NRC, 2013; Stevens et al., 2009), because this can raise students' conceptualization in science learning and by recognizing the interdisciplinarity, help to develop students' work and life skills, for example, solving problems, making justified decisions, and conceptualizing the nature of science as related to work and life components of science education. For example, an understanding of genetic variability and DNA (both suggested as disciplinary core ideas in biology) can help to conceptualize the topic of hereditary diseases, why these occur and how these need to be treated medically. An understanding of climate change (a disciplinary idea in geography) can help to understand the topic of climate change, why this occurs, and potential actions needed by society.

\section{Work and Life Skills}

Work and life skills are central to a competency-based curriculum (Estonian Government, 2011). By grouping work and life skills as tools for working (information literacy; information and communication technology), ways of working (communication; collaboration and teamwork), ways of thinking (creativity and innovation; critical thinking; problem-solving; decision-making, learning to learn, and metacognition), and living in the world (citizenship; life and career; personal and social responsibility), it is suggested these relate either to future careers or responsible citizens that can be seen as science-related and associated with scientific challenges (Binkley et al., 2012; Salonen et al., 2017).

Work and life skills play a major role in science education. Science education can play a very important role in promoting work and life skills seen as shaping students for the future (Binkley et al., 2012; Salonen et al., 2017). As Kwon (2008) 
points out, enabling students to use core interdisciplinary abilities, such as thinking critically (ways of thinking), are one of the fundamental aims of education and can facilitate student learning, for example, solve problems, justify, and argue decisions in science-related situations. Work and life skills (or capabilities) are supported by other abilities such as the promotion of responsible citizenship, through which society can shape a better world, giving students a sense of sustainability and also values (Alazzi \& Chiodo, 2008; Westheimer, 2015). For students to succeed, especially in science or science-related careers, research skills (tools for working), for example, creating research questions (Anderson, 2002) and the related mindset for scientific research are important, whereas core interdisciplinary ideas viewed as important to succeed in today's society is the ability to solve, often complex, problems (Mainzer, 2009). While several authors (Binkley et al., 2012; Salonen et al., 2017; Westheimer, 2015) have indicated different work and life skills, which are important at the workplace and in everyday life, these are not well-studied especially with respect to how students themselves evaluate and value work and life skills.

\section{Perceived Self-efficacy and Importance}

Perceived self-efficacy has been defined as a person's evaluation of their abilities to organize or perform activities that require conceptualization of different core ideas (Bandura, 1986; Choi et al., 2011; OECD, 2016). Thayne (2013) has recognized that in science learning, as well in other areas, self-efficacy is often attributed to an individual's level of motivation. Several studies have shown that higher perceived self-efficacy contributes significantly to possessing the necessary motivation in science education and achieving the desired outcome (Pajares, 1996; Schunk, 1991). As Bandura and other researchers have shown, perceived self-efficacy can have an impact on everything, from psychological state to motivation to behavior.

The concept of perceived importance has been empirically demonstrated to be related to the individual, although compared with students' perceived self-efficacy; perceived importance has a more lasting value (Thelk et al., 2009). It has been studied in several educational studies, for example, both in motivational and technological studies (Ciampa, 2013; Sharp, 2018). Perceived importance is also used in test creation as it can show whether an individual perceives a test as important or not.

\section{METHODOLOGY}

\section{Research Sample}

To develop a model interrelating perceived self-efficacy and its importance with core ideas associated with science learning and its value related to work and life skills development, data collection was undertaken from Grade $8(n=218) 14-15$ years old and Grade $11(\mathrm{n}=95) 17-18$ years old students, from five different Estonia schools (both rural and city); this being taken as a convenience sample. Before undertaking data collection, the objectives of the research were introduced to students, teachers, and parental consent and were collected on paper. The total sample number was 313 students (146 boys and 167 girls). Both Grades 8 and 11 students were included in this research because it allowed seeing the current situation at both middle and secondary school levels.

\section{Instrument and Procedures}

An instrument previously developed (Soobard et al., 2018), but slightly modified, was used in this study. Items that were shown previously to have a low factor weight were removed from the instrument, and other items, such as items related to interdisciplinary core ideas, were added. Although the previous instrument measured only students' perceived self-efficacy, determination of importance toward core ideas was added.

The instrument (questionnaire) was compiled in two parts; the first part, obtaining data on students' perceived self-efficacy and its importance toward disciplinary and interdisciplinary core ideas and, second, a section focusing on work and life skills.

\section{Instrument Development}

This research used a paper and pencil questionnaire, created in two parts.

1. The first part consisted of 24 statements, answered using a 4-point Likert scale $(1-$ I do not agree at all to 4 - I definitely agree), related to disciplinary and interdisciplinary core ideas, for example:

"Development of the fetus"

"Working principle of an electricity generator"

"The consequences of destroying rainforest on my own wellbeing"

"Natural and human-made systems change over time"

These core ideas were divided into four sub-areas, accordingly to a previously conducted Principal Component Analysis (Soobard et al., 2018) plus confirmative factor analysis, used in this research to ensure validity:

- Disciplinary core ideas in biology and chemistry (8 statements);

- Disciplinary core ideas in physics (8 statements);

- Disciplinary core ideas in geography (earth science) (4 statements);

- Interdisciplinary core ideas (4 statements).

2. The second part of the instrument consisted of 32 work and life skills statements, using a 4-point Likert scale (1 - I disagree to 4 - I totally agree), for example:

"I can use creative thinking to solve scientific problems";

"I feel responsibility for what happens in the environment";

"I can design the most appropriate strategy to solve problems";

"I am motivated to solve challenging problems."

The statements were divided into seven categories, accordingly to previously determined categories using Principal Component Analysis (Soobard et al., 2018) and Confirmative Factor analysis: 
- Cognitive skills (5 statements);

- Critical thinking (4 statements);

- The changeability of scientific knowledge (5 statements);

- Responsible citizenship (5 statements);

- Mind-set for scientific research (3 statements);

- The roles of science lessons (4 statements);

- And problems solving skills (6 statements).

\section{Validity and Reliability}

The validity and reliability of the created instrument and methodology used for validation are shown in Table 1. The compiled instrument was validated by ten science teachers, who participated (October 2017-January 2018) in a professional development course, and four scientists from the University of Tartu. The instrument validators thoroughly checked both the statements contained in the questionnaire and the overall structure. In the light of the experts' opinion, a few complex items (perceived as too difficult for students to understand) were removed from the questionnaire.

\section{Data Analysis}

For the first and second part of the research, descriptive statistics (mean, standard deviation, and statistical significance) and reliability were conducted using SPSS version 24 and presented in Table 1. To increase the interpretation of the instrument outcomes, the statistical program Mplus (Version 7) (Muthén \& Muthén, 1998-2015) was used for confirmatory factor analysis (CFA) and parallel analysis. CFA and the related models were created to raise the interpretability of the entire questionnaire and results with respect to the internal structure (Lewis, 2017).

To evaluate the meaningfulness of the created models in Mplus, criteria for fit indexes, proposed by Bowen and Guo (2012) were used, based on the following criteria: Root mean square error of approximation (RMSEA): Close fit: $\leq 0.05$, reasonable fit: 0.05-0.08, poor fit: $\geq 0.10$; Bentler's comparative fit index (CFI): $\leq 0.95$; the Tucker-Lewis index (TLI): $0 \leq 0.95$.
Parallel analysis (as a method for determining the number of factors to be retained from the CFA) was used to investigate whether factors should be excluded from the study. To interpret the data, suggestions by Garrido et al. (2016) were used to guide considerations of fit indices, after establishment of the eigenvalue solution, (this meaning each of a set of values of a parameter for which a different equation has a non-zero solution - an eigenfunction under the given conditions), based, first on CFI and TLI, and then RMSEA.

\section{RESEARCH RESULTS}

The 24 items in the first part of the instrument gave four factors (Figures 1 and 2). The CFA showed that the four perceived self-efficacy and importance factors from core ideas topics could be differentiated as disciplinary core ideas in biology and chemistry (f1), disciplinary core ideas in physics (f2), disciplinary core ideas in geography (f3), and interdisciplinary core ideas (f4) (Appendix Table 1).

The model fit statistics (Chi-square, RMSEA, CFI, and TLI) (Table 2) indicated that the models were statistically significant and had good quality characteristics. The RMSEA value showed a reasonable fit, and also, the CFI, and TLI values showed good fit with the created models (Bowen \& Guo, 2012). Thus, on examining the following fit statistics (Chi-square, CFU, and TLI), these indicated a fit for both models.

Observing the correlation coefficients, it was evident that the strength of the items was strong between the four factors. This indicated the suitability of undertaking the parallel analysis. To explore the factor structure even further, exploratory factor analysis was conducted with parallel analysis. Based on the results of the parallel analysis, the four core ideas factors from the CFA were divided into two factors. These were renamed accordingly.

\section{Table 1: Validation and reliability of a created instrument for this research}

\begin{tabular}{|c|c|c|}
\hline Instrument/method & Validity/reliability & Used validation/reliability method \\
\hline \multirow{4}{*}{$\begin{array}{l}\text { Students perceived self-efficacy and importance toward } \\
\text { disciplinary and interdisciplinary core ideas related to } \\
\text { work and life skills/4-point Likert scale questionnaire }\end{array}$} & Content validity & $\begin{array}{l}\text { Expert opinion method: Agreement by } 14 \text { independent experts in } \\
\text { the field of science education }\end{array}$ \\
\hline & Construct validity & $\begin{array}{l}\text { Analysis of Estonian middle and secondary science curriculum } \\
\text { and syllabus to ensure that items are valid in terms of expected } \\
\text { learning outcomes; Mplus confirmatory factor analysis models }\end{array}$ \\
\hline & Reliability & Cronbach alpha $=0.87$ over the sample (with each factor over 0.75 ) \\
\hline & & $\begin{array}{l}\text { Mplus confirmatory factor analysis and related models were used } \\
\text { to determine the suitability of the internal structure (Lewis, 2017) }\end{array}$ \\
\hline
\end{tabular}

Table 2: Model fit statistics for confirmatory factor analysis for students' perceived self-efficacy and importance models using a 4-point Likert scale

\begin{tabular}{lcc}
\hline Model fit statistics & Self-efficacy & Importance \\
\hline$\chi^{2}$ & $607.32(\mathrm{df}=246 ; \rho<0.001)$ & $817.30(\mathrm{df}=246 ; \rho<0.001)$ \\
Root mean square error of approximation & $0.07(\rho<0.001)$ & $0.09(\rho<0.001)$ \\
Comparative fit index & 0.92 & 0.94 \\
Tucker-Lewis index & 0.91 & 0.93 \\
\hline
\end{tabular}




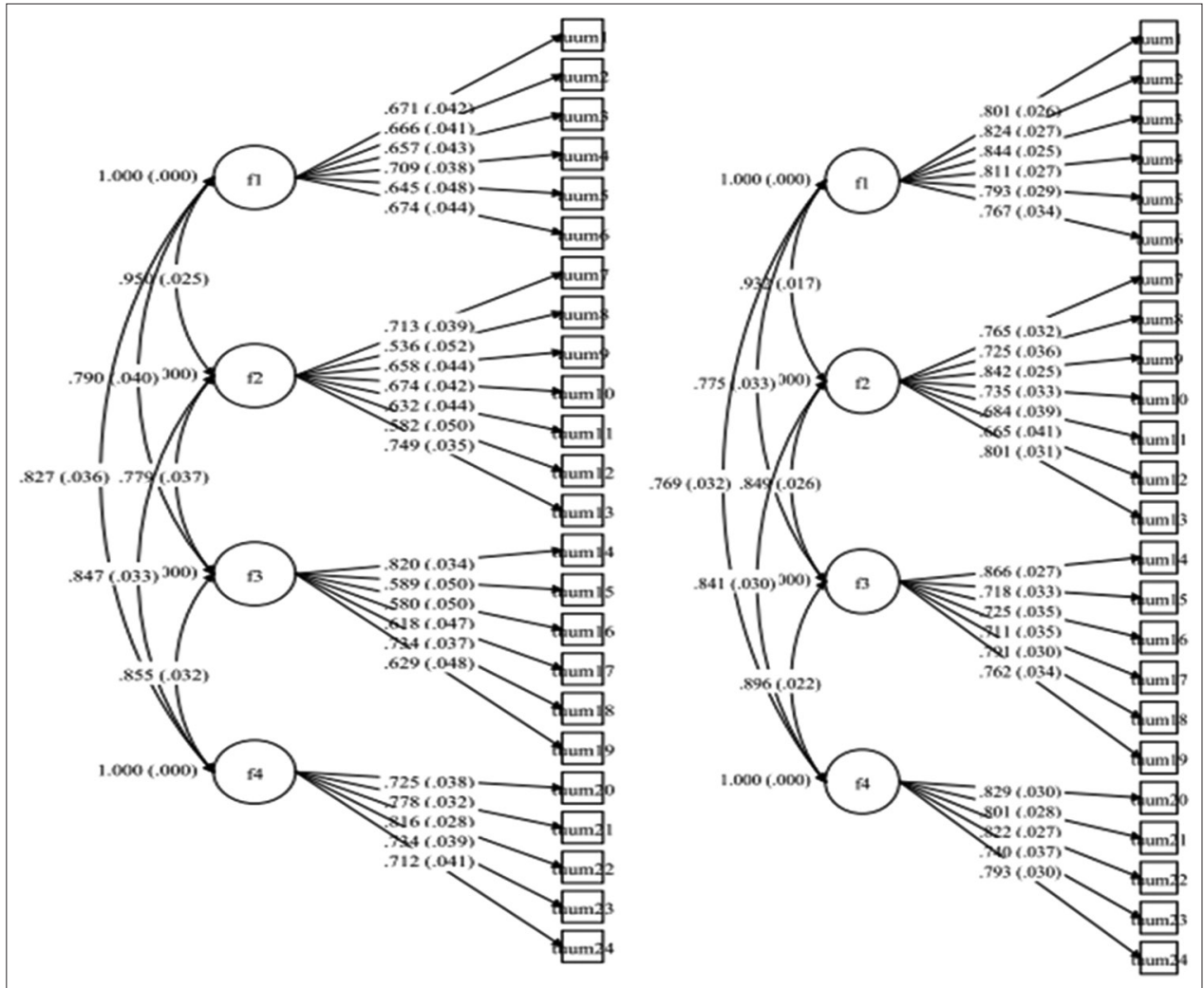

Figure 1: Models of confirmatory factor analysis of core ideas in science education (standardized values). On the left-hand side of Figure 1 is the Grade 8 students' perceived self-efficacy model, and in the right side is the importance model

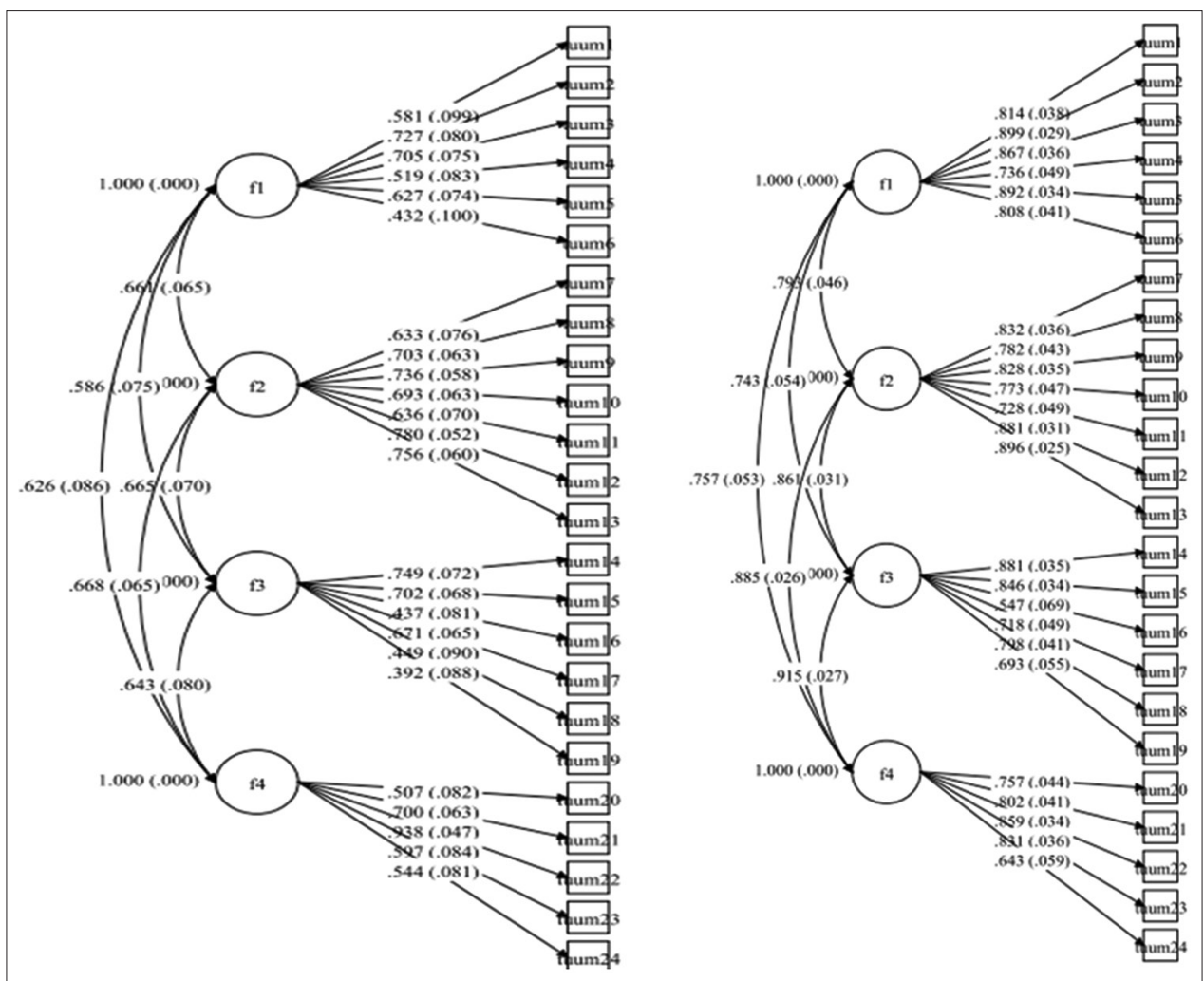

Figure 2: Models of confirmatory factor analysis of core ideas in science education (standardized values). On the left-hand side of Figure 2 is the Grade 11 students' perceived self-efficacy model, and in the right side is the importance model 
The following table (Table 3) shows Grades 8 and 11 students' perceived self-efficacy toward disciplinary and interdisciplinary core ideas.

The results in Table 3 show that students evaluated the mean perceived self-efficacy toward disciplinary and interdisciplinary core ideas higher than the average $(\mathrm{M}=2.50)$. In both Grades 8 and 11, students' self-efficacy toward disciplinary and interdisciplinary ideas are shown to be higher than average.

Table 4 shows Grades 8 and 11, students' mean perceived importance toward disciplinary and interdisciplinary core ideas.

These results show that students evaluated the mean perceived importance toward disciplinary and interdisciplinary core ideas lower than average $(\mathrm{M}=2.50)$. This is of concern because, based on students' opinions, they do not value these disciplinary and interdisciplinary core ideas.

Figures 3 and 4 show how the 32 items in the first part of the instrument can be divided among the seven factors by undertaking CFA and indicates that seven of the perceived self-efficacy and importance factors from work and life skills can be differentiated. These are labeled as: Cognitive skills (f1),

\begin{tabular}{|c|c|c|c|c|}
\hline \multirow[t]{2}{*}{ Factors names } & \multicolumn{2}{|c|}{ Grade 8} & \multicolumn{2}{|c|}{ Grade 11} \\
\hline & Mean & SD & Mean & SD \\
\hline $\begin{array}{l}\text { Disciplinary core ideas in biology, } \\
\text { chemistry, geography, and physics } \\
\text { (f1 and f3) } 12 \text { statements }\end{array}$ & 2.64 & 0.85 & 2.56 & 0.79 \\
\hline $\begin{array}{l}\text { Interdisciplinary core ideas } \\
\text { (f2 and f4) } 12 \text { statements }\end{array}$ & 2.50 & 0.85 & 2.81 & 0.81 \\
\hline
\end{tabular}

Table 4: Grades 8 and 11 perceived importance toward core ideas. Measured with Likert 4-point scale

\begin{tabular}{lccccc}
\hline \multirow{2}{*}{ Factors names } & \multicolumn{2}{c}{ Grade 8 } & & \multicolumn{2}{c}{ Grade 11 } \\
\cline { 2 - 3 } \cline { 5 - 6 } & Mean & SD & & Mean & SD \\
\hline $\begin{array}{l}\text { Disciplinary core ideas in biology, } \\
\text { chemistry, geography, and physics }\end{array}$ & 2.39 & 0.92 & & 2.37 & 0.88 \\
(f1 and f3) 12 statements & & & & \\
$\begin{array}{l}\text { Interdisciplinary core ideas } \\
\text { (f2 and f4) 12 statements }\end{array}$ & 2.38 & 0.90 & & 2.29 & 0.90 \\
\hline
\end{tabular}

the roles of science lessons (f2), the changeability of scientific knowledge (f3), responsible citizenship (f4), critical thinking (f5), mindset for scientific research (f6), and problem-solving skills in everyday life situations (f7) (Appendix Table 2).

From an interpretation of model fit statistics (Chi-square, RMSEA, CFI, and TLI), the model is shown to be statistically significant and has good quality characteristics. A statistically significant RMSEA value ensures the avoidance of issues of sample size (it analyses the discrepancy between the hypothesized models, with optimally chosen parameter estimates). The RMSEA value shows reasonable fit. The CFI and TLI compare the fit of a target model to the fit of an independent model. CFI and TLI values show good fit (Bowen $\&$ Guo, 2012). Table 5 shows model fit statistics.

The correlation coefficients show that the strength of the items is strong between the two factors. To explore the factor structure even further, exploratory factor analysis was carried out with parallel analysis. (Parallel analysis has proven consistently accurate in determining the significant components, variable loadings, and analytical statistics when decomposing a correlation matrix). The parallel analysis suggested that the five factors should be separated based on eigenvalues. (Eigenvalues are each of a set of values of a parameter for which a differential equation has a non-zero solution (an eigenfunction) under the given conditions).

Based on the results of the parallel analysis, the seven work and life skills factors from the CFA were divided into five factors, which were renamed accordingly. Table 6 shows Grades 8 and 11 , students' perceived self-efficacy with respect to work and life skills factors.

Table 7 showed that Grades 8 and 11 students' perceived selfefficacy toward factors of work and life skills were higher than average $(M=2.50)$. The highest students' perceived self-efficacy was toward the factor on the changeability of scientific knowledge. The students' perceived self-efficacy toward cognitive and problem solving-skills was much lower for both grade levels.

Table 7 showed that Grades 8 and 11 students' mean perceived importance toward factors of work and life skills were higher than average $(\mathrm{M}=2.50)$. This suggested that students' value different work and life skills. Students' perceived importance toward the factor changeability of scientific knowledge was highest, for example, and with the respect to the statement "I feel responsible for what happens in environment" Grade 11

Table 5: Model fit statistics for confirmatory factor analysis for students' perceived self-efficacy and importance models using a 4-point Likert scale

\begin{tabular}{lcc}
\hline Model fit statistics & Self-efficacy & Importance \\
\hline$\chi^{2}$ & $867.91(\mathrm{df}=443 ; \rho<0.001)$ & $1178.95(\mathrm{df}=443 ; \rho<0.001)$ \\
Root mean square error of approximation & $0.06(\rho<0.001)$ & $0.07(\rho<0.001)$ \\
Comparative fit index & 0.91 & 0.88 \\
Tucker-Lewis index & 0.90 & 0.86 \\
\hline
\end{tabular}




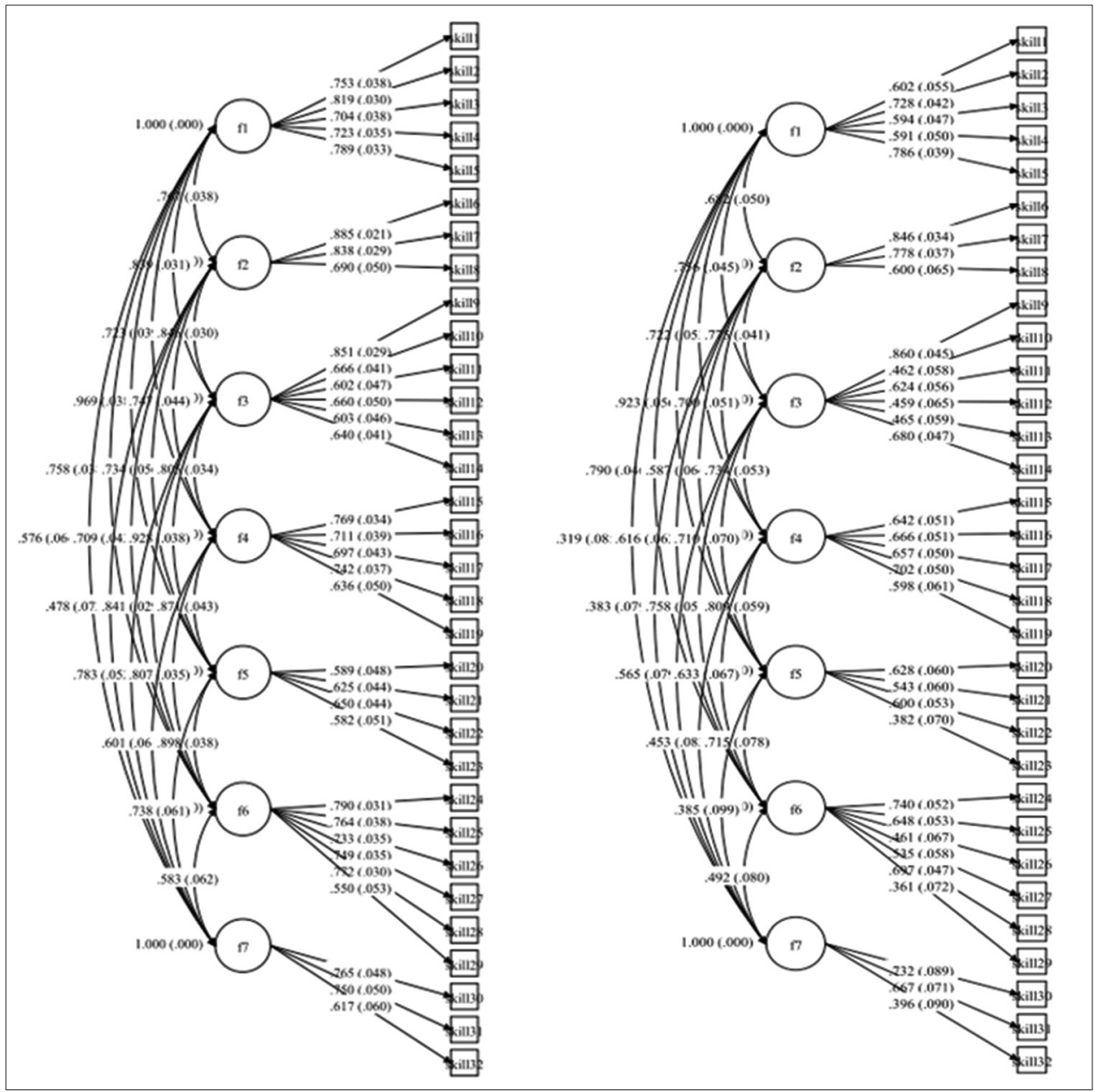

Figure 3: Models of confirmatory factor analysis of work and life skills in science education (standardized values). On the left-hand side of Figure is the Grade 8 students' perceived self-efficacy model and in the right side is the importance model

students mean perceived importance toward that was high $(\mathrm{M}=3.41)$. Students' perceived importance toward cognitive and problem-solving skills and the role of science lessons and mindset for scientific research factors was lower compared to the other factors.

\section{DISCUSSION AND CONCLUSIONS}

Previous studies have shown that secondary school students' perceived self-efficacy toward science learning is high; this was noticeably lower in learning work and life skills (Soobard \& Rannikmäe, 2015). Furthermore, the research was undertaken by Soobard et al. (2018) indicated that Grade 12 students' perceived self-efficacy utilizing work and life skills was much lower in some areas (e.g., problem-solving skills), compared with others, such as creativity and imagination. Despite previous studies, there remains a gap between science learning and societal needs. Therefore, there is still confusion in which science learning and work and life skills to differentiate and consider while investigating students perceived self-efficacy and importance.

Therefore, this research's aim was to present models and find out which core ideas and work and life skills factors could be
Table 6: Grades 8 and 11 perceived self-efficacy toward core ideas associated with work and life skills. Measured with Likert 4-point scale

\begin{tabular}{lcccccc}
\hline \multirow{2}{*}{ Factors } & \multicolumn{2}{c}{ Grade 8 } & & \multicolumn{2}{c}{ Grade 11 } \\
\cline { 2 - 3 } & Mean & SD & & Mean & SD \\
\hline $\begin{array}{l}\text { Cognitive and problem-solving skills } \\
\text { (f1 and f7) 11 statements }\end{array}$ & 2.74 & 0.81 & & 2.63 & 0.81 \\
$\begin{array}{l}\text { The roles of science lessons and } \\
\text { mind-set for scientific research }\end{array}$ & 2.73 & 0.85 & & 2.65 & 0.83 \\
(f2 and f6) 7 statements & & & & & \\
$\begin{array}{l}\text { The changeability of scientific } \\
\text { knowledge (f3) 5 statements }\end{array}$ & 3.09 & 0.83 & & 3.37 & 0.61 \\
$\begin{array}{l}\text { Responsible citizenship (f4) 5 } \\
\text { statements }\end{array}$ & 2.71 & 0.89 & & 2.84 & 0.87 \\
Critical thinking (f5) 4 statements & 2.82 & 0.81 & & 2.85 & 0.74 \\
\hline
\end{tabular}

differentiated from students' samples. The conducted research and CFA models provide insights into whether a relationship between a set of observed variables and their underlying construct exists. The models give an overview of the students' assessments of the various factors allowing easier management and interpretation of the entire data set. 


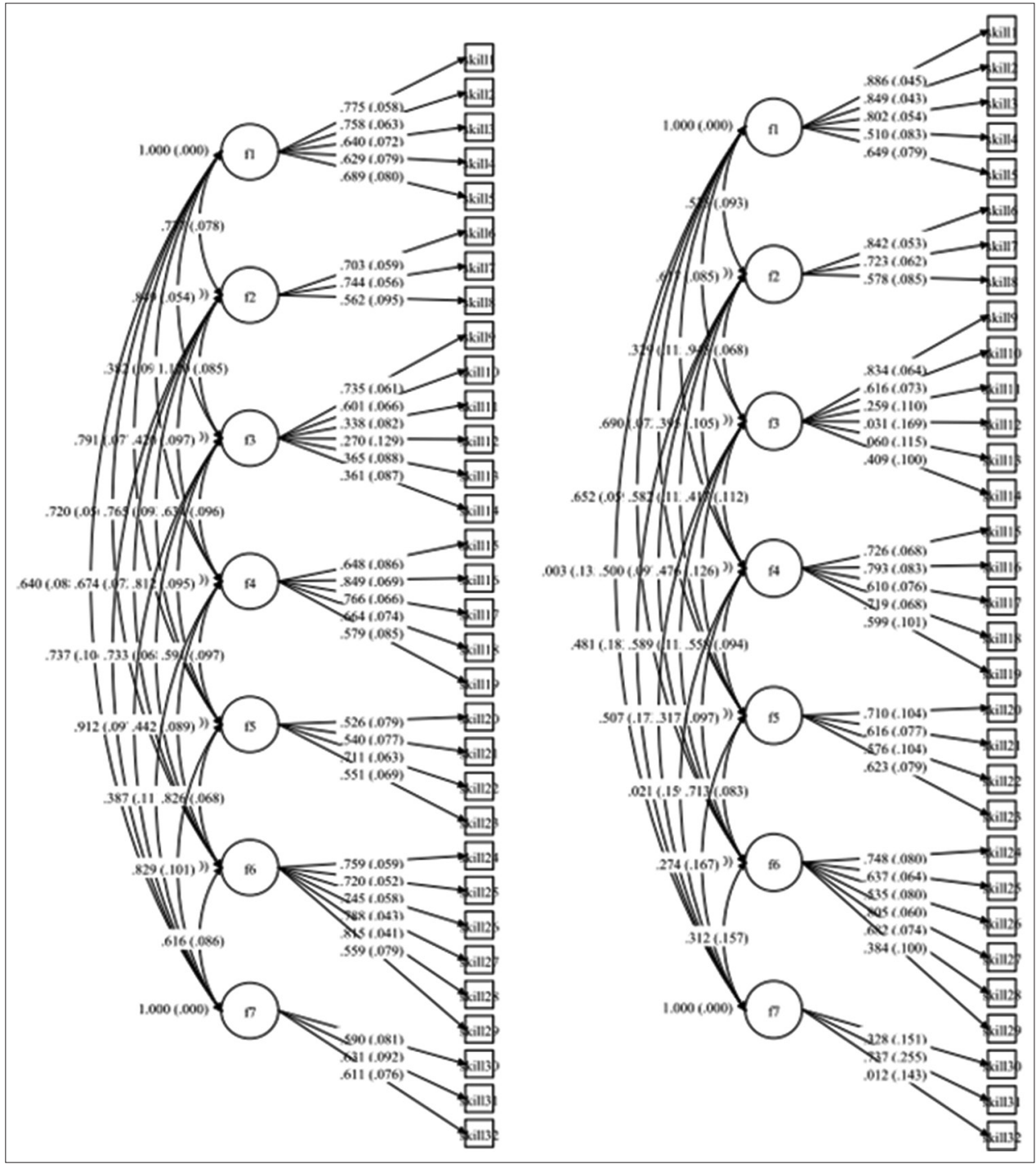

Figure 4: Models of confirmatory factor analysis of work and life skills in science education (standardized values). On the left-hand side of Figure 4 is the Grade 11 students' perceived self-efficacy model and in the right side is the importance model

Table 7: Grades 8 and 11 perceived importance toward work and life skills. Measured with Likert 4-point scale

\begin{tabular}{lccccc}
\hline \multirow{2}{*}{ Factors } & \multicolumn{2}{c}{ Grade 8} & & \multicolumn{2}{c}{ Grade 11 } \\
\cline { 2 - 3 } \cline { 6 - 7 } & Mean & SD & & Mean & SD \\
\hline $\begin{array}{l}\text { Cognitive and problem-solving skills } \\
\text { (f1 and f7) 11 statements }\end{array}$ & 2.60 & 0.88 & & 2.62 & 0.85 \\
$\begin{array}{l}\text { The role of science lessons and mindset for } \\
\text { scientific research (f2 and f6) 7 statements }\end{array}$ & 2.58 & 0.92 & & 2.62 & 0.87 \\
$\begin{array}{l}\text { The changeability of scientific } \\
\text { knowledge (f3) 5 statements }\end{array}$ & 2.90 & 0.90 & & 3.15 & 0.73 \\
$\begin{array}{l}\text { Responsible citizenship (f4) 5 statements } \\
\text { Critical thinking (f5) 4 statements }\end{array}$ & 2.68 & 0.92 & & 2.90 & 0.88 \\
\hline
\end{tabular}

For both Grades 8 and 11, students' perceived self-efficacy and importance models were similar. Krajcik and Delen (2017) emphasized core ideas and their importance in science education; similarly, the models in this study also revealed that these could be divided into two as disciplinary and interdisciplinary core ideas. The CFA model with collapsed factors gave satisfactory results with two factors with both samples (Grades 8 and 11):

- Disciplinary core ideas in biology, chemistry, geography, and physics;

- And interdisciplinary core ideas.

There were strong correlations between these core ideas. The reason why students' perceived self-efficacy and importance toward core ideas topics in biology, chemistry, geography, and physics was similar could be that the topics taught in these subjects were closely related. Nevertheless, it was important to link these with everyday life (Teppo et al., 2017).

Students, in both Grades 8 and 11, had high perceived selfefficacy toward disciplinary and interdisciplinary core ideas. Therefore, it was important to use these core ideas and to integrate core ideas such as models and systems into different areas. These interdisciplinary core ideas could be transferred to other subjects, for example, energy has its own meaning in 
physics (light energy) and in biology (metabolism). Thayne (2013) recognized that in science learning self-efficacy was often attributed to an individual's level of motivation, and it was thus important to implicate this knowledge into science learning and use these disciplinary and interdisciplinary core ideas. This suggested that the learning context made the disciplinaryand interdisciplinary ideas more exciting for the students, but also the stronger involvement of a work and life skills and career component allowed students to shape their awareness of these areas.

Findings indicated that while students' mean perceived self-efficacy for different ideas was greater than the average and thus, in general, they considered their self-efficacy in these disciplinary and interdisciplinary ideas high, they did not consider these ideas to be important. This was seen as very problematic because an appreciation of these disciplinary and interdisciplinary ideas could help to solve various problems, or to explain phenomena, etc. (Krajcik \& Delen 2017; Harlen et al., 2010, 2015). This suggested that there was a need for teachers to rethink how these disciplinary and interdisciplinary ideas were presented.

As the created CFA models for work and life skills reveal, similar changes occur in the five different work and life skills factors:

- Cognitive and problem-solving skills;

- The role of science lessons and mindset for scientific research;

- The changeability of scientific knowledge;

- Responsible citizenship;

- Critical thinking.

All work and life skills are needed in science-related careers (OECD, 2016; Bybee \& McCrae, 2011). As the students' perceived self-efficacy and importance toward disciplinary and interdisciplinary ideas is low, it indicates that students' work and life skills and have not grown over time. For both Grades 8 and 11 , students' self-efficacy and importance toward the cognitive skills and problem-solving skills are among the lowest compared with the other factors. This is problematic, as cognitive skills and the development of these skills are important for conceptualizing and reflecting on ways of solving today's problems, for example, global warming, environmental degradation, and non-sustainable agriculture (EC, 2010). The underlying cognitive skills must be well understood by students, for example, to read, think, understand, and solve problems efficiently - when cognitive skills are weak, then academic learning is likely to be a struggle (Kwon, 2008). As with previous research (Soobard et al., 2018), attention is drawn to the fact that student's self-efficacy remains low related to utilization of problem-solving skills.

Students' perceived self-efficacy and indications of importance toward the roles of science lessons and students' mindset, with respect to scientific research, are shown to be among the lowest factors. These factors cover items, such as scientific models (DNA), undertaking data collection, science lessons develop useful skills, and values.
In both Grades 8 and 11, students' self-efficacy toward values are low. However, values are important in today's society, for example, responsible citizenship gives students a sense of sustainability and values and actions which contribute to building community values and practices which, in turn, help to improve the world (Westheimer, 2015; Alazzi \& Chiodo, 2008). Despite numerous studies confirming that values are important there is still the issue - students' perceptions toward values are low. It is important to link values with the disciplinary and interdisciplinary core ideas and therefore to raise the awareness of values important to the students.

Students' perceived importance toward the role of science lessons, and mindset for scientific research, cognitive and problem-solving skills, and responsible citizenship is among the lowest, which indicates that students do not consider these important. Other research (Westheimer, 2015; Alazzi \& Chiodo, 2008) point out that being a responsible citizen follows society rules and laws, within which students emphasize the importance of helping other people and the need to follow rules - to succeed in today's society is the ability to solve complex problems (Mainzer, 2009; Anderson, 2002).

As the Estonia curriculum is competency-based (Estonian Government, 2011) emphasizing the development of students' skills, it is worrying that students' perceived self-efficacy and importance toward important work and life skills increase little over time. A possible reason may be that schools do not pay much attention to the development of competences above and beyond content acquisition. With this in mind, it may be important to determine more closely, how students evaluate a variety of work and life skills and the reasons for their views. One of the reasons for this may be that it is difficult to give students feedback frequently on work and life skills because it is hard for teachers to assess work and life skills.

The results of this study indicate students' perceived selfefficacy and importance vary on different factors. It is necessary that students understand that these work and life skills are important in science-related careers and in their everyday life, as several studies have shown that students' higher perceived self-efficacy contributes significantly to finding the necessary motivation in science education and achieving the desired result in acquiring skills (Pajares, 1996; Schunk, 1991). All the more reason that in today's world people need to be ready to adapt quickly with faced unexpected problems and to use different skills.

\section{Recommendations}

Based on this research, the following recommendations can be put forward:

1. In order that science education is more integrated with reallife situations, more attention needs to be paid to the teaching approach. Based on the research outcomes, it is important that in teaching, the content of the teaching material is more closely related to different competences and so that students can raise their perceived self-efficacy and importance toward core ideas and related work and life skills. 
2. Conceptualization around different disciplinary and interdisciplinary core ideas can make it easier for both teachers and students to relate different gained knowledge and thus make learning more effective.

3. A further recommendation is that in school lessons, more emphasis needs to be placed on the development of disciplinary and interdisciplinary core ideas. It is important to emphasize interdisciplinary core ideas, for example, models and systems because these are transferrable into different disciplines and therefore can be developed in different subjects.

4. It is also important to consider naming these work and life skills as attributes for work and life because these also include characteristics such as responsible citizenship and mindset for scientific research as well. It is also important to carry out professional development courses about disciplinary and interdisciplinary core ideas and how to include these into their teaching process.

5. It is important that skills and knowledge are developed together in the learning process. In this research, it is suggested that this learning content could be arranged through disciplinary and interdisciplinary ideas, which are helping students to understand the surrounding world.

6. It is important to put more emphasis on science education and to raise all work and life skills for students and that to avoid such gaps.

7. It is suggested that it is meaningful to create study material from core ideas as a map, which outlines how the disciplinary and interdisciplinary ideas have developed over multiple school years while, at the same time, emphasizing science content and also highlighting work and life skills and science-related careers.

8. It is important to raise student's awareness of that and include the science lessons more the interdisciplinarity of the models (DNA, globe, atom, and lenses as models in science education) and with that to raise student's selfefficacy toward these. There is a need to promote students' understanding of models and also the valuing of the roles of science lessons.

\section{Limitations}

This research focused only on different students in Grades 8 and 11 , and therefore it was not possible to describe how students' views changed during their learning over this timespan. Only paper and pencil instruments were used for data collection, and there was no possibility to clarify students' responses at a later stage (e.g., using interviews). Even though this research concluded that highly correlated factors could be combined, this still raised the question whether it was reasonable to determine these factors together. While interpreting results from the present research, an important need to keep in mind was that the research was based on both Grades 8 and 11 students' answers. In addition, several items were left out from the final factor structure. It was also important to consider the need for future studies with $11^{\text {th }}$ grade students.

\section{REFERENCES}

Alazzi, K., \& Chiodo, J.J. (2008). Perceptions of social studies students about citizenship: A study of Jordanian middle and high school students. The Educational Forum, 72(3), 271-280.

Anderson, R.D. (2002). Reforming science teaching: What research says about inquiry. Journal of Science Teacher Education, 13(1), 1-12.

Bandura, A. (1986). Social Foundations of Thought and Action: A Social Cognitive Theory. Englewood Cliffs, NJ: Prentice-Hall.

Binkley, M., Erstad, O., Herman, J., Raizen, S., Ripley, M., Miller-Ricci, M., \& Rumble, M. (2012). Defining $21^{\text {st }}$ century skills. In: McGaw, B., \& Care, E. (Eds.), Assessment and Teaching of $21^{\text {st }}$ Century Skills. New York: Springer. p17-66.

Bowen, N.K., \& Guo, S. (2012). Structural Equation Modeling. New York: Oxford University Press.

Bybee, R., \& McCrae, B. (2011). Scientific literacy and student attitudes: Perspectives from PISA 2006 science. International Journal of Science Education, 33(1), 7-26.

Choi, K., Lee, H., Shin, N., Kim, S., \& Krajcik J. (2011). Re-Conceptualization of scientific literacy in South Korea for the $21^{\text {st }}$ century. Journal of Research in Science Teaching, 48(6), 670-697.

Ciampa, M. (2013). Student perceived importance and correlations of selected computer literacy course topics. Journal of Instructional Pedagogies, 11, 1-15.

Clark, E. (1997). Designing and Implementing an Integrated Curriculum: A Student-Centered Approach. Brandon, Vermont: Holistic Education Press.

Estonian Government. (2011). National Curriculum for Gymnasium. Regulation of the Government of the Republic of Estonia, Tallinn. Available from: https://www.riigiteataja.ee/akt/174787. [Last accessed on 2019 Sep 24].

European Commission (EC). (2010). New Skills for New Jobs: Action Now. Published by the Education, Audiovisual and Culture Executive Agency (EACEA P9 Eurydice). Available from: http://www.aic.lv/bolona/2010/ Reports/New skills for new jobs2011.pdf. [Last accessed on 2019 Sep 24].

Garrido, L.E., Abad, F.J., \& Ponsoda, V. (2016). Are fit indices really fit to estimate the number of factors with categorical variables? Some cautionary findings via Monte Carlo simulation. Physical Methods, 21, 94.

Greeno, J.G., \& Engeström, Y. (2014). Learning in activity. In: Sawyer, R.K., (Ed.), The Cambridge Handbook of the Learning Sciences. Cambridge: Cambridge University Press. p128-147.

Harlen, W., Devés, R., Garza, G.F., Léna, P., Millar, R., Reiss, M., Rowell, P., \& Yu, W. (2015). Working with Big Ideas of Science Education. Hartfield, Herts: Association for Science Education College Lane. p6-24.

Harlen, W., Devés, R., Garza, GF., Léna, P., Millar, R., Reiss, M., Rowell, P., \& Yu, W. (2010). Principles and Big Ideas of Science Education. Hartfield, Herts: Association for Science Education College Lane. p42-51.

Hildebrand, D.L. (2018). Experience is not the whole story: The integral role of the situation in Dewey's democracy and education. Journal of Philosophy of Education, 52(2), 287-300.

Holbrook, J., \& Rannikmae, M. (2009). The meaning of scientific literacy. International Journal of Environmental and Science Education, 4(3), $275-288$

Holbrook, J., \& Rannikmäe, M. (2010). Contextualisation, decontextualisation, re-contextualisation. A science teaching approach to enhance meaningful learning for scientific literacy. In: Eilks, I., \& Ralle, B. (Eds.), Contemporary Science Education. Herzogenrath: Shaker Verlag. p69-82.

Krajcik, J., \& Delen, I. (2017). Engaging learners in STEM education. Estonian Journal of Education, 5(1). DOI: 10.12697/eha.2017.5.1.02b.

Kwon, N. (2008). A mixed-methods investigation of the relationship between critical thinking and library anxiety among undergraduate students in their information search process. College and Research Libraries, 69, 117-131.

Lewis, T.F. (2017). Evidence regarding the internal structure: Confirmatory factor analysis. Measurement and Evaluation in Counseling and Development, 50(4), 239-247.

Mainzer, K. (2009). Challenges of complexity in the $21^{\text {st }}$ century. An interdisciplinary introduction. European Review, 17, 219-236. 
Muthén, L.K., \& Muthén, B.O. (1998-2015). Mplus User 's Guide. $7^{\text {th }}$ ed. Los Angeles, CA: Muthén and Muthén.

National Research Council (NRC). (2007). Taking Science to School: Learning and Teaching Science in Grades K-8. Washington, DC: The National Academies Press.

National Research Council (NRC). (2013). Next Generation Science Standards: For States, By States. Washington, DC: The National Academies Press.

OECD. (2016). Students' Attitudes Towards Science and Expectations of Science Related Careers. In: PISA 2015 Results. Vol. 1: Excellence and Equity in Education. Paris: OECD Publishing.

Osborne, J., Simon, S., \& Collins, S. (2003). Attitudes towards science: A review of the literature and its implications. International Journal of Science Education, 25(9), 1049-1079.

Pajares, F. (1996). Self-efficacy beliefs in academic settings. Review of Educational Research, 66, 543-578.

Salonen, A., Hartikainen-Ahia, A., Hense, J., Scheersoi, A., \& Keinonen, T. (2017). Secondary school students' perceptions of working life skills in science-related careers. International Journal of Science Education, 39, 1339-1352.

Schunk, D.H. (1991). Self-efficacy and academic motivation. Educational Psychologist, 26, 207-231.

Sharp, L.A. (2018). Collaborative digital literacy practices among adult learners: Levels of confidence and perceptions of importance. International Journal of Instruction, 11(1), 153-166.
Soobard, R., \& Rannikmäe, M. (2015). Examining curriculum related progress using a context-based test instrument a comparison of Estonian grade 10 and 11 students. Science Education International, 26(3), 263-283.

Soobard, R., Semilarski, H., Holbrook, J., \& Rannikmäe, M. (2018). Grade 12 students' perceived self-efficacy towards working life skills and curriculum content promoted through science education. Journal of Baltic Science Education, 17(5), 838-850.

Stevens, S., Sutherland, L., \& Krajcik, J.S. (2009). The Big Ideas of Nanoscale Science and Engineering. Arlington, VA: National Science Teachers Association Press.

Teppo, M., Semilarski, H., Soobard, R., \& Rannikmäe, M. (2017). Grade nine students' learning motivation and interest towards science topics presented in different contexts. Estonian Journal of Education, 5(1), 130-170.

Thayne, S.W. (2013). Facilitating Language Learner Motivation: Teacher Motivational Practice and Teacher Motivational Training. All Theses and Dissertations. Paper, No. 4026. Available from: http://www. scholarsarchive.byu.edu/etd/4026. [Last accessed on 2019 Sep 24].

Thelk, A.D., Sundre, D.L., Horst, S.J., \& Finney, S.J. (2009). Motivation matters: Using the student opinion scale to make valid inferences about student performance. The Journal of General Education, 58, 129-151.

Van Aalsvoort, J. (2004). Logical positivism as a tool to analyse the problem of chemistry's lack of relevance in secondary school chemical education. International Journal of Science Education, 26(9), 1151-1168.

Westheimer, J. (2015). What kind of Citizen? Educating Our Children for the Common Good. New York: Teachers College Press. 


\section{APPENDIX}

Modeling Grades 8 and 11 students' perceived self-efficacy and importance toward disciplinary and interdisciplinary ideas and work and life skills.

\begin{tabular}{|c|c|c|c|c|c|}
\hline \multirow[t]{2}{*}{ Disciplinary and interdisciplinary core ideas } & \multirow[t]{2}{*}{ Factor loads } & \multicolumn{2}{|c|}{ Self-efficacy } & \multicolumn{2}{|c|}{ Importance } \\
\hline & & M & SD & M & SD \\
\hline \multicolumn{6}{|l|}{ Disciplinary core ideas on biology and chemistry (f1) } \\
\hline Cell functions in various human tissues & 0.67 & 2.30 & 0.78 & 2.19 & 0.93 \\
\hline Comparing the efficiency of aerobic and anaerobic respiration in the human muscle & 0.59 & 2.29 & 0.87 & 2.33 & 0.92 \\
\hline Redox reactions in everyday life & 0.55 & 2.03 & 0.90 & 2.08 & 0.93 \\
\hline Energy conversion from one form into another & 0.55 & 2.31 & 0.89 & 2.22 & 0.95 \\
\hline Matter and energy exchange in living organisms & 0.53 & 2.72 & 0.76 & 2.45 & 0.87 \\
\hline Development of the fetus & 0.46 & 2.59 & 0.85 & 2.42 & 0.90 \\
\hline The basic hereditary process & 0.40 & 2.29 & 0.83 & 2.28 & 0.93 \\
\hline Hereditary of genetic diseases & 0.36 & 2.14 & 0.83 & 2.15 & 0.95 \\
\hline \multicolumn{6}{|l|}{ Disciplinary core ideas in physics (f2) } \\
\hline Working principle of an electricity generator & 0.80 & 2.42 & 0.91 & 2.27 & 0.96 \\
\hline Newton's laws of motion & 0.70 & 2.73 & 0.85 & 2.47 & 0.89 \\
\hline Sound transmission & 0.62 & 2.60 & 0.84 & 2.48 & 0.93 \\
\hline Our solar system planets and other small celestial bodies & 0.56 & 2.97 & 0.77 & 2.47 & 0.88 \\
\hline Ideas that are controlled and tested by models & 0.51 & 2.22 & 0.89 & 2.19 & 0.92 \\
\hline Perception of change in a moving elevator & 0.46 & 2.41 & 0.91 & 2.25 & 0.89 \\
\hline Natural phenomena at the particulate level & 0.40 & 2.40 & 0.83 & 2.23 & 0.91 \\
\hline The nature of interactions between bodies & 0.35 & 2.68 & 0.83 & 2.39 & 0.92 \\
\hline \multicolumn{6}{|l|}{ Disciplinary ideas in geography (f3) } \\
\hline The consequences of destroying rainforest on my own well-being & 0.75 & 2.75 & 0.91 & 2.58 & 0.99 \\
\hline Relief deformation and climate change & 0.67 & 2.48 & 0.89 & 2.24 & 0.92 \\
\hline Climate warming potential consequences for Estonia & 0.59 & 2.78 & 0.83 & 2.71 & 0.92 \\
\hline Solar and lunar eclipse & 0.54 & 2.89 & 0.87 & 2.44 & 0.97 \\
\hline \multicolumn{6}{|l|}{ Interdisciplinary core ideas (f4) } \\
\hline Systems creation & 0.68 & 2.37 & 0.86 & 2.36 & 0.96 \\
\hline Causes and effects of events & 0.62 & 2.64 & 0.82 & 2.55 & 0.92 \\
\hline Natural and human-made systems change over time & 0.57 & 2.51 & 0.85 & 2.42 & 0.94 \\
\hline Structural properties of the objects and systems & 0.53 & 2.33 & 0.90 & 2.20 & 0.89 \\
\hline
\end{tabular}




\section{Table 2: Grades 8 and 11 self-efficacy and importance toward work and life skills}

Self-efficacy Importance

M SD

M

SD

Cognitive skills (f1)

I can use creative thinking to sole scientific problems

I can solve science problems

I can explain that science and technology are evolve together

I can defend my standpoint using scientific evidence, when I am arguing in scientific topics

I continue trying to solve a problem despite difficulties

The roles of science lessons (f2)

In my opinion, science lessons develop useful skills for solving problems in everyday life

In my opinion, science lessons develop skills needed to control thinking and action during the problem-solving process

I can apply knowledge from science lessons in new situations

In my opinion, science lessons have developed values

The changeability of scientific knowledge (f3)

I try to understand the reasons for other peoples' actions instead of judging them

I show respect for other human beings regardless of their cultural backgrounds and nationalities

In my opinion scientific knowledge can change

I can explain natural phenomena $\times$ s in everyday life

The usefulness of scientific knowledge depends on how and for what purpose they are used

Responsible citizenship (f4)

When I make decisions, I consider the positive and negative consequences toward the natural environment

I feel responsibility for what happens in environment

My personal well-being is connected to what happens in nature at a global level

In future, I would like to work in a position where I can contribute to protecting the natural environment

In problem-solving, I am sensitive to ethical standards which are valued by society

Critical thinking (f5)

I evaluate the efforts and the effectiveness of selected strategies after reaching the desired goal

I can critically evaluate the quality of information

I can distinguish scientific evidence from non-scientific

Creativity and imagination are important factors for establishing scientific knowledge

Mindset for scientific research (f6)

In my opinion, scientific models (like DNA) portray nature as it actually exists

In my opinion, carefully collected data will give perfect knowledge

In my opinion, there is only one certain scientific method for creating scientific knowledge

Problem-solving skills in everyday life situations (f7)

In my opinion, science lessons have helped me to understand the characteristics of scientific knowledge

Before I start to solve problems, I make sure whether the problem is within my level of understanding or I need extra help

I evaluate the efforts and the effectiveness of a selected strategy even when I do not reach the desired goal

I can design the most appropriate strategy to solve problem

I can find alternative strategies if an initial method does not work

I am motivated to solve challenging problems

\begin{tabular}{|c|c|c|c|c|}
\hline 0.73 & 2.93 & 0.72 & 2.73 & 0.84 \\
\hline 0.72 & 2.72 & 0.68 & 2.50 & 0.83 \\
\hline 0.53 & 2.59 & 0.91 & 2.30 & 0.87 \\
\hline 0.52 & 2.46 & 0.77 & 2.34 & 0.91 \\
\hline 0.51 & 2.63 & 0.76 & 2.41 & 0.86 \\
\hline 0.80 & 2.68 & 0.91 & 2.64 & 0.99 \\
\hline 0.75 & 2.82 & 0.94 & 2.66 & 0.96 \\
\hline 0.73 & 2.74 & 0.81 & 2.65 & 0.89 \\
\hline 0.62 & 2.98 & 0.87 & 2.94 & 0.96 \\
\hline 0.71 & 3.16 & 0.82 & 3.11 & 0.90 \\
\hline 0.71 & 3.41 & 0.90 & 3.40 & 0.89 \\
\hline 0.67 & 3.38 & 0.78 & 3.03 & 0.90 \\
\hline 0.53 & 2.80 & 0.73 & 2.53 & 0.86 \\
\hline 0.48 & 3.06 & 0.59 & 2.71 & 0.58 \\
\hline 0.71 & 2.82 & 0.89 & 2.86 & 0.95 \\
\hline 0.65 & 3.13 & 0.86 & 3.03 & 0.92 \\
\hline 0.52 & 2.94 & 0.90 & 2.90 & 0.93 \\
\hline 0.37 & 2.32 & 0.93 & 2.39 & 0.96 \\
\hline 0.70 & 2.66 & 0.91 & 2.64 & 0.92 \\
\hline 0.63 & 2.70 & 0.77 & 2.43 & 0.85 \\
\hline 0.59 & 2.91 & 0.63 & 2.90 & 0.88 \\
\hline 0.49 & 3.00 & 0.74 & 2.72 & 0.90 \\
\hline 0.70 & 2.87 & 0.62 & 2.67 & 0.65 \\
\hline 0.74 & 2.69 & 0.87 & 2.50 & 0.90 \\
\hline 0.72 & 2.93 & 0.87 & 2.62 & 0.91 \\
\hline 0.54 & 2.23 & 0.87 & 2.23 & 0.90 \\
\hline 0.47 & 2.98 & 0.84 & 2.68 & 0.85 \\
\hline 0.64 & 3.03 & 0.76 & 2.97 & 0.88 \\
\hline 0.62 & 2.93 & 0.80 & 2.84 & 0.93 \\
\hline 0.55 & 2.67 & 0.77 & 2.85 & 0.93 \\
\hline 0.43 & 2.79 & 0.77 & 2.88 & 0.90 \\
\hline 0.82 & 2.48 & 0.60 & 2.61 & 0.63 \\
\hline
\end{tabular}

